\title{
An Analysis of the Challenges and Prospects of Tourism Sector of CHT: A Study on Khagrachari
}

\author{
Asifa Nargis $^{1^{*}} \quad$ Kamrul Hossain ${ }^{1,2}$ \\ 1.Lecturer, Department of Management, Rangamati Science and Technology University Rangamati, \\ Rangamati-4500, Bangladesh \\ 2.MBA (Marketing), Department Of Marketing, Comilla University,Kotbari, Comilla, Bangladesh
}

\begin{abstract}
Tourism is the most emerging industry in the world. Before the pandemic, it was very much growing. It has a great contribution to national GDP as well as global GDP. According to World Travel and Tourism Council (WTTC), in 2019 tourism sectors have contributed $10.4 \%$ of the global GDP which is equal to US\$ 9.2 trillion to the global Gross Domestic Product (GDP) whereas in 2020 tourism sectors have contributed 5.5\% of the global GDP which is equal to US\$ 4.7 trillion to the global Gross Domestic Product (GDP). In 2019 tourism sectors have created 334 million jobs which were $10.4 \%$ of total employment in 2019 but in 2020, 62 million jobs were lost, representing a drop of $18.5 \%$, leaving just 272 million employed across the sector globally. It has been found out that during 2014-2019, 1 in every 4 net new jobs created across the world is in the travel and tourism field but in 2020 it is only 1 in every 11 net new jobs created. This research paper has been conducted on the problems and prospects of the tourism sector of khagrachari one of the hill districts of Chittagong hill tracts (CHT). Khagrachari is a very popular and attractive tourist destination for both domestic and foreign tourists. The challenges that the researchers had found out through this research paper are Transportation facilities, Electricity service, accommodation facilities, Security, the interest of local tourists, Condition of roads and highways, internet service, Tourist guides, information regarding tourist spots. Besides, prospects that were found through this research paper are tribal foods, bridges are under construction, employment opportunity, Income level, Standard of living, Crime reduction, beautification, economic development. Finally, here the researcher has provided some recommendations for overcoming these challenges.
\end{abstract}

Keywords: Tourism, CHT, Challenges, Prospects.

DOI: $10.7176 / \mathrm{EJBM} / 13-18-05$

Publication date:September $30^{\text {th }} 2021$

\section{Introduction}

The movement of people to other countries or other places for personal or business purposes to refresh themselves can be defined as tourism. People are always busy with their daily work. Sometimes they become bored with such monotonous work. So when people get some break from their monotonous life, they want to visit tourist spots to entertain themselves. Nowadays tourism is one of the growing sectors in the world. The tourism sector has a great impact on the economy of any certain place as well as on the national economy. Its contribution to our national GDP in 2019 was $2.7 \%$ whereas in 2020 it was $1.7 \%$ of our national GDP. Although 1859 people got the job in the travel and tourism sector in Bangladesh in 2019 but in 2020 it declines to 1452 which was equal to $2.3 \%$ of the total employment. This research paper is conducted on the challenges and prospects of the tourism sector of khagrachari, a hill district of Bangladesh. Transportation, electricity, accommodation, security, roads and highways, internet, lack of information on websites is the major challenges that are come out through this research paper. On the other hand, employment opportunity, income level, the standard of living, infrastructure development, tribal foods, growth of hotels and restaurants are the major prospects of the tourism sector in khagrachari. Here the researcher uses a sample size of 100 respondents. For data analysis, the researcher uses SPSS software. At last, the researchers give some recommendations to overcome these challenges for the betterment of the tourism sector in khagrachari.

\section{Background of the study}

Bangladesh is a center of tourism. Every year a large number of tourists are visiting this country. Like other sectors, tourism is one of the important sectors for our country to earn foreign currencies. Although we earn USD 142.9 MN from the international visitors in 2020 but we earned USD 354.5 MN from the international visitors in 2019 which was equal to $0.8 \%$ of our total exports. Many countries of the world are now focusing on this sector to increase their earnings. By focusing on and developing this sector Bangladesh also can improve its economy. Although the travel and tourism sector contributed only 5.5\% of global GDP in 2020 but in 2019 this sector contributed $10.4 \%$ of the total global GDP. In 2019, 334 MN people got the job in travel and tourism sector whereas in 2020 it declines to $272 \mathrm{MN}$ due to pandemic situation. Bangladesh has many tourist spots around the country and Khagrachari is one of them. Khagrachari is full of high hills, clouds, mysterious cave, waterfalls, lakes, hanging bridges, rivers, large temples, etc. Alutila Hill, Richhang Waterfall, KHDC 
Horticulture Park, Dighinala Maniker Dighi, Alutila Cave, Panichari Buddha Sculpture, Dighinala Touduchari Waterfall, Sajek and Marissa Valley, Nunchari Debota Pond, Banyan Tree more than Hundred Years Old, Mong King's Palace, Sindukchari Pond, JolPahar Matiranga, Agriculture Research Centre, Lakshmichari Waterfall, Sapachari Waterfall. Tourists can feel all types of adventurous here. Those who want some relief from their routinized life they can visit khagrachari as a place of relaxation. For this tourism sector of khagrachari must have to be developed by the authority. But in the way of development of tourism sector, there are some challenges have to be overcome. Transportation was the main challenge a few years ago. All the bridges were made of steel. Most of the roads were so much uncomfortable that only jeep (cader gari) was the only way to move tourist's destinations from the Sadar Upazila. People were irritated with electricity service because maximum places were out of electricity. Before 2008 there were no internet facilities. The security system was not up to the mark. Accommodation facilities were not satisfactory level. There were only 4-5 hotels and motels in khagrachari that was not enough to meet the needs of the tourists. Information regarding tourists' spots, distance, transport, accommodation, food, etc was not available on the website. Although in the recent year some development has done by the government and local authority but to increase the number of tourists in Khagrachari or overall in our country the government has to take more steps. Because if the number of tourist increase then the new business will develop on that areas and huge employment opportunity will be created. More hotels and motels will be established. The income level of people will rise as a result standard of living will be changed.

\section{Research aim}

The aim of the research paper is to find out the challenges and prospects of the tourism sector of Khagrachari which is a Hill district of CHT. Here, the researcher will provide some recommendations and suggestions to overcome the challenges and bring out maximum positive impact on the tourism sector of Khagrachari.

\section{Research objectives}

In this research study, the researcher set some objectives that are given in the following:

$>$ To assess the present challenges of the tourism sector of Khagrachari.

$>$ To find out some prospects that can be achieved by overcoming challenges.

$>$ To provide some recommendations to overcome the challenges and bring maximum positive impact on the tourism sector of Khagrachari.

\section{Literature review}

The CHT is situated in the southeastern part of Bangladesh with a total area of 5,089 sq. miles (13,189 sq.km.), and shares borders with both India and Myanmar (Khan 2015). The CHT consists of three different hill districts, namely the Rangamati, Bandarban and Khagrachari hill districts. Historically, 11 ethnic groups out of these 54, have been dwelling in the Chittagong Hill Tracts (CHT) for centuries before colonization (Uddin 2010), and the remaining 43 groups have been living in the north, southwest, northeast, and northwest of Bangladesh.

According to Lamb and Davidson (1996), transportation is crucial in the tourism industry, as it connects supply (production) and demand (market) directly. The role of transportation in tourism is essentially to provide accessibility. It has been widely claimed by many scholars that without accessibility, tourism simply cannot take place (Chew 1987, Prideaux 2000). On 24th June 1 person was spotted dead and two people were heavily injured in an accident between two jeeps in Dhighinala Upazila (Prothom Alo). On 23rd January 2021 on the place, another man died in an accident between two jeeps (Prothom Alo,)

According to USAID, Rural tourism is a rapidly growing sector of the global tourism industry. Since rural tourism operations are often in remote locations, ensuring a reliable supply of energy can be a special challenge. Therefore, planning for reliable energy is vital and impacts all decisions made at rural tourism facilities - since these areas may have difficult access to fossil fuel supplies and no access to grid electric power. Sajek valley the most attractive tourism destination in khagrachari has no electricity facility. Here people use solar energy or generator and after $11 \mathrm{pm}$ the generator supply is stopped by the hotel owner. According to the manager of hotel gairing, they have to burn 15-20 liters of diesel per day to operate their daily hotel operations (Prothom Alo).

Logically, the development of the accommodation sector should be a fundamental element of the overall destination planning process. It is demonstrated that the failure to plan and control the accommodation sector has meant that the official policies for tourism development have not been achieved (Sharpley 2000). The accommodation sector is not developed so much yet in khagrachari. Many tourists passing their night in sajek valley under open sky when it is a holiday because during the holiday it is very much impossible to provide accommodation facilities to a large number of tourists by only a few cottages and where most of of the cottage have only 7-10 rooms. During the holiday tourists have to pay 2500 taka in the Sadar area and 3500-8000 taka in sajek valley.

Security is the main concern for tourists. Before the peace agreement between the Bangladesh government 
and Parbattya Chattagram Janasonghati Somity (PCJSS) on December 2, 1997 hill tracts were very risky for the tourists because during 1971-1997 many people were killed in CHT. For the betterment of the local people, the Bangladesh government set up many army camps along with BDR camps, police camps, etc. According to the CHT Commission, there are more than 230 army camps, more than 100 BDR camps, and over 80 police camps in the CHT. All of them are working for the security of the local people and peace.

Although we are living in a very modern era but before 2008 there was no mobile networking service in khagrachari. The land phone was the only way to talk with others. although $10^{\text {th }}$ May, 2008 khagrachari comes under the mobile network but still now 4G internet services is not available in khagrachari. Mobile networking speed is very much slow outside the Sadar area. Although in sajek valley the most attractive tourist attraction in khagrachari has only two mobile operators network named Robi and Airtel but their internet speed is very much slow.

Roads and highways are very risky in khagrachari. Tourists want to travel on the safest roads where roads will be wider so that drivers can drive their vehicles easily. A youth was killed and 10 others were heavily injured when a bus fell into a ditch in manikchari on January 24, 2021(Prothom Alo). On the other hand, 8 people were injured in the bridge that collapsed in dighinala on December 26, 2020 (Prothom Alo). Due to the lack of roads, or the poor condition of the existing roads, and due to the low level of road safety, in some tourist destinations, there may be a decrease in traffic for tourist needs. This means that a developed tourism must be preceded by a developed road infrastructure. (Ramadan Mazrekaj, 2020)

Food is one of the most attractions for culinary tourists. Food experiences can add value to tourism (Hall et al., 2003; Hjalager \& Richards, 2002) since food is a key aspect of the travel experience and essential to understanding the culture of the place visited (Getz, Robinson, Andersson, \& Vujicic, 2014). Tourists want to taste the local food. Every tourist's place has something unique for the tourists.

The tourism sectors not only contribute to the GDP but also play a significant role in terms of providing employment opportunities, reducing poverty, increasing income distribution. (Liu Jia 2007) believes that tourism consumption has general characteristics of consumption, and there is a close correlation between tourism consumption and disposable income and prices: tourism consumption is positively related to disposable income and negatively related to prices.

According to the Bangladesh tourism board, more than 4 million manpower is in extreme distress due to covid 19 situation and at least 15 million people who depend on them are in grave danger as they are unemployed. On the other hand according to the Pacific Asia Travels Association the tourism industry of Bangladesh has lost about TK. 10000 core from January 2020 to June 2020. It is also estimated that Bangladesh is facing a loss of around TK 20000 crore due to the epidemic. In the 2021-2022 financial year, TK 4032 crore has been allocated for the civil aviation and tourism sector. Although TK 364 crore budget allocation is increased in this sector than the previous financial year when the allocation was TK 3668 only 625 crores has been allocated for the development of the tourism sector.

According to the World Trade Organization (WTO), before the pandemic, Travel \& Tourism (including its direct, indirect, and induced impacts) accounted for 1 in 4 of all new jobs created across the world, $10.6 \%$ of all jobs (334 million), and 10.4\% of global GDP (US\$9.2 trillion). Meanwhile, international visitor spending amounted to US\$1.7 trillion in 2019 (6.8\% of total exports, $27.4 \%$ of global services exports). (WTTC)

Dr. M. Afjal Hossain, a Professor of Tourism and Hospitality Management Department at DU said, "As Bangladesh is witnessing rapid development in infrastructure, the tourism sector will be able to make a major contribution to the national economy within the next five years, with the number of foreign and domestic tourists greatly increasing".

Tourism is an important and dynamic sector for the world economy and for developing countries like Bangladesh (Chowdhury, Fahim, \& Dooty, 2013). As a promising alternative tourism sector along with the export sector has a positive effect on the economy like employment generation, impacts on the expansion of linked industries, and poverty alleviation (Khondker \& Ahsan, 2015). Tourists can be attracted by making the information about the tourism sector available to the tourist (Nabi \& Zaman, 2014).

\section{Research methodology}

Research design and methodology deal with the processing of raw data of a research study. It has defined how the entire research work has been decorated as per research requirements. This study is based on the impact of challenges and prospects of the tourism sector khagrachari. In the case of research methods both qualitative and quantitative research methods will be used by the researcher. Through qualitative research, the researcher tries to find out depth on information from the respondents about the required data. Through this method, the researcher can bring out why any situation occurred and how this situation occurred. Through the quantitative research method, quantitative data is collected by the researcher that can be expressed numerically. For collecting numeric data the researcher has to survey a pre-specified sample of respondents from which the researcher can collect the required data. Although it is an expensive mood of data collection but through this research, the 
researcher gets more accurate information rather than the qualitative method. For data collection, the researcher has followed both primary and secondary data collection techniques. After data collection, the researcher has focused on the sampling techniques that were used to select a standard sample size that represents the total population. Here a sample size of 100 has been taken. All the respondents of this research paper were tourists and local people of khagrachari. For the data analysis, the researcher also used SPSS.

\section{Research limitations}

At the time of conducting research study the researcher faced some limitations that are given in the following:

$>$ The researcher has lack of experience over conducting research

$>$ Time limitation

$>$ Word limitation

$>$ Data accuracy

$>$ Respondents' unwillingness to provide data.

\section{Analysis}

\begin{tabular}{|l|l|l|}
\hline Measures & Frequency & Percentage (\%) \\
\hline Gender & & \\
Male & 65 & 65 \\
Female & 35 & 35 \\
Total & 100 & 100 \\
\hline Age & & \\
Below 20 years old & 5 & 5 \\
21-35 years old & 60 & 60 \\
36-50 years old & 24 & 24 \\
51 years and above & 11 & 11 \\
Total & 100 & 100 \\
\hline Education & & \\
Under graduation & 17 & 17 \\
Graduation & 51 & 51 \\
Post-graduation & 32 & 32 \\
Total & 100 & 100 \\
\hline tourists types & & \\
Local & 38 & 38 \\
Others & 62 & 62 \\
Total & 100 & 100 \\
\hline Income & & \\
TK 0- TK 15000 & 14 & 14 \\
TK 16000- TK 30000 & 47 & 47 \\
TK 31000- TK 45000 & 16 & 16 \\
TK 46000 above & 23 & 23 \\
Total & 100 & 100 \\
\hline Source: field survey, 2021 & & \\
\hline
\end{tabular}

Source: field survey, 2021

Table 1: Descriptive statistics of "demographic variables.

From the research study, it can be said that $65 \%$ of respondents are male and $35 \%$ of respondents are female. Here $5 \%$ of respondents' age are below 20 years, $60 \%$ of respondents' age are in between $21-35$ years, $24 \%$ of respondents' ages are in between 36-50 years, and the rest of the respondent's ages are above 51 years. Here undergraduate respondents are $17 \%$, graduate respondents are $51 \%$ and post-graduate respondents are $32 \%$. Here out of $100 \%$ respondents $38 \%$ respondents are local people and $62 \%$ respondents are from outside of khagrachari. $14 \%$ of respondents' income are below TK 15000, 47\% of respondents' income are below TK 16000- TK 30000 whereas $16 \%$ of respondents' income are in between TK 31000- TK 45000, and the rest of $23 \%$ of respondents income are above TK 46000.

\section{Correlation analysis}

Correlation means the statistical relationship between two variables. It can be used to identify the strength of the relationships between two entities. There are three types of correlations. These are positive correlation, negative correlation, and zero or no correlation. When two variables move in the same direction then it can be said positive correlation that would be by 1 . If two variables move in the opposite direction then it can be said as a negative correlation between entities that would be -1 . Besides if there two entities move totally unrelated direction then it is called zero or no correlation between two entities. Pearson product-moment correlation 
coefficient denoted by $r$. Here $r=+1$ means a perfect positive relationship. On the contrary, -1 indicates a perfect negative relationship between two entities. Besides, $r=0$ means, there is no relationship between the two variables. Correlation ( $\mathrm{p}$-value) is significant at the 0.01 level that indicates when $\mathrm{p}$-value $<0.01$ means statistically significant when p-value $>0.01$ means statistically insignificant.

Correlations of Challenges

\begin{tabular}{|c|c|c|c|c|c|c|c|c|c|}
\hline & & \begin{tabular}{|c|} 
CHALLE \\
NGES
\end{tabular} & $\mathrm{TF}$ & ES & $\mathrm{AF}$ & ST & RH & IS & ITS \\
\hline \multirow{3}{*}{$\begin{array}{l}\text { CHALLEN } \\
\text { GES }\end{array}$} & Pearson Correlation & 1 & $.688^{* *}$ & $.771^{* *}$ & $.711^{* *}$ & $.792^{* *}$ & $.934^{* *}$ & $.966^{* *}$ & $.882^{* *}$ \\
\hline & Sig. (2-tailed) & & .000 & .000 & .000 & .000 & .000 & .000 & .000 \\
\hline & $\mathrm{N}$ & 100 & 100 & 100 & 100 & 100 & 100 & 100 & 100 \\
\hline \multirow[t]{3}{*}{$\mathrm{TF}$} & Pearson Correlation & $.688^{* *}$ & 1 & $.934^{* *}$ & $.977^{* *}$ & $.925^{* *}$ & $.742^{* *}$ & $.651^{* *}$ & $.859^{* * *}$ \\
\hline & Sig. (2-tailed) & .000 & & .000 & .000 & .000 & .000 & .000 & .000 \\
\hline & $\mathrm{N}$ & 100 & 100 & 100 & 100 & 100 & 100 & 100 & 100 \\
\hline \multirow[t]{3}{*}{$\mathrm{ES}$} & Pearson Correlation & $.771^{* *}$ & $.934^{* *}$ & 1 & $.963^{* *}$ & $.978^{* *}$ & $.821^{* *}$ & $.728^{* *}$ & $.896^{* *}$ \\
\hline & Sig. (2-tailed) & .000 & .000 & & .000 & .000 & .000 & .000 & .000 \\
\hline & $\mathrm{N}$ & 100 & 100 & 100 & 100 & 100 & 100 & 100 & 100 \\
\hline \multirow[t]{3}{*}{$\mathrm{AF}$} & Pearson Correlation & $.711^{* *}$ & $.977^{* *}$ & $.963^{* *}$ & 1 & $.948^{* *}$ & $.770^{* *}$ & $.673^{* *}$ & $.873^{* * *}$ \\
\hline & Sig. (2-tailed) & .000 & .000 & .000 & & .000 & .000 & .000 & .000 \\
\hline & $\mathrm{N}$ & 100 & 100 & 100 & 100 & 100 & 100 & 100 & 100 \\
\hline \multirow[t]{3}{*}{ ST } & Pearson Correlation & $.792^{* *}$ & $.925^{* *}$ & $.978^{* *}$ & $.948^{* *}$ & 1 & $.850^{* *}$ & $.762^{* *}$ & $909^{* * *}$ \\
\hline & Sig. (2-tailed) & .000 & .000 & .000 & .000 & & .000 & .000 & .000 \\
\hline & $\mathrm{N}$ & 100 & 100 & 100 & 100 & 100 & 100 & 100 & 100 \\
\hline \multirow[t]{3}{*}{$\mathrm{RH}$} & Pearson Correlation & $934^{* *}$ & $.742^{* *}$ & $.821^{* *}$ & $.770^{* *}$ & $.850^{* *}$ & 1 & $.909^{* *}$ & $921^{* * *}$ \\
\hline & Sig. (2-tailed) & .000 & .000 & .000 & .000 & .000 & & .000 & .000 \\
\hline & $\mathrm{N}$ & 100 & 100 & 100 & 100 & 100 & 100 & 100 & 100 \\
\hline \multirow[t]{3}{*}{ IS } & Pearson Correlation & $966^{* *}$ & $.651^{* *}$ & $.728^{* *}$ & $.673^{* *}$ & $.762^{* *}$ & $.909^{* *}$ & 1 & $.868^{* * *}$ \\
\hline & Sig. (2-tailed) & .000 & .000 & .000 & .000 & .000 & .000 & & .000 \\
\hline & $\mathrm{N}$ & 100 & 100 & 100 & 100 & 100 & 100 & 100 & 100 \\
\hline \multirow[t]{3}{*}{ ITS } & Pearson Correlation & $.882^{* *}$ & $.859^{* *}$ & $.896^{* *}$ & $.873^{* *}$ & $.909^{* *}$ & $.921^{* *}$ & $.868^{* *}$ & 1 \\
\hline & Sig. (2-tailed) & .000 & .000 & .000 & .000 & .000 & .000 & .000 & \\
\hline & $\mathrm{N}$ & 100 & 100 & 100 & 100 & 100 & 100 & 100 & 100 \\
\hline
\end{tabular}

**. Correlation is significant at the 0.01 level (2tailed).

Table 2: Correlations of Challenges.

The result of Pearson correlation coefficient (r) shows that transportation facility $(\mathrm{TF})(\mathrm{r}=.688, \mathrm{p}<0.01)$, electricity service (ES) $(r=.771, p<0.01)$, accommodation facilities (AF) $(r=.711, p<0.01)$, security for tourists (ST) $(\mathrm{r}=.792, \mathrm{p}<0.01)$, internet service (IS) $(\mathrm{r}=.966, \mathrm{p}<0.01)$, condition of roads and highways $(\mathrm{RH})(\mathrm{r}=.934$, $\mathrm{p}<0.01)$, information regarding tourist spots (ITS) $(\mathrm{r}=.882, \mathrm{p}<0.01)$.

The analysis found that the factors i.e., transportation facility, electricity service, accommodation facilities, security for tourists, internet service, condition of roads and highways, information regarding tourists spots are significantly correlated with the challenges of tourism sectors of Khagrachari. 
Correlations of Prospects

\begin{tabular}{|c|c|c|c|c|c|c|c|c|c|}
\hline & & $\begin{array}{c}\text { PROSP } \\
\text { ECTS }\end{array}$ & DTF & EO & $\mathrm{IL}$ & SL & ED & NHR & ID \\
\hline \multicolumn{2}{|c|}{ PROSPECTS Pearso } & 1 & $.892^{* *}$ & $.909^{* *}$ & $.954^{* *}$ & $.922^{* *}$ & $.881^{* *}$ & $.910^{* *}$ & $.909^{* *}$ \\
\hline & Sig. (2-tailed) & & .000 & .000 & .000 & .000 & .000 & .000 & .000 \\
\hline & $\mathrm{N}$ & 100 & 100 & 100 & 100 & 100 & 100 & 100 & 100 \\
\hline \multirow[t]{3}{*}{ DTF } & Pearson Correlation & $.892^{* *}$ & 1 & $.962^{* *}$ & $.920^{* *}$ & $.975^{* *}$ & $.966^{* *}$ & $.983^{* *}$ & $.986^{* *}$ \\
\hline & Sig. (2-tailed) & .000 & & .000 & .000 & .000 & .000 & .000 & .000 \\
\hline & $\mathrm{N}$ & 100 & 100 & 100 & 100 & 100 & 100 & 100 & 100 \\
\hline \multirow[t]{3}{*}{$\mathrm{EO}$} & Pearson Correlation & $.909^{* *}$ & $.962^{* *}$ & 1 & $.946^{* *}$ & $.968^{* *}$ & $.949^{* *}$ & $.976^{* *}$ & $.979^{* *}$ \\
\hline & Sig. (2-tailed) & .000 & .000 & & .000 & .000 & .000 & .000 & .000 \\
\hline & $\mathrm{N}$ & 100 & 100 & 100 & 100 & 100 & 100 & 100 & 100 \\
\hline \multirow[t]{3}{*}{ IL } & Pearson Correlation & $.954^{* *}$ & $.920^{* *}$ & $.946^{* *}$ & 1 & $.960^{* *}$ & $.900^{* *}$ & $.944^{* *}$ & $.943^{* *}$ \\
\hline & Sig. (2-tailed) & .000 & .000 & .000 & & .000 & .000 & .000 & .000 \\
\hline & $\mathrm{N}$ & 100 & 100 & 100 & 100 & 100 & 100 & 100 & 100 \\
\hline \multirow[t]{3}{*}{ SL } & Pearson Correlation & $.922^{* *}$ & $.975^{* *}$ & $968^{* *}$ & $.960^{* *}$ & 1 & $954^{* *}$ & $.991^{* *}$ & $.988^{* *}$ \\
\hline & Sig. (2-tailed) & .000 & .000 & .000 & .000 & & .000 & .000 & .000 \\
\hline & $\mathrm{N}$ & 100 & 100 & 100 & 100 & 100 & 100 & 100 & 100 \\
\hline \multirow[t]{3}{*}{ ED } & Pearson Correlation & $.881^{* *}$ & $.966^{* *}$ & $.949^{* *}$ & $.900^{* *}$ & $.954^{* *}$ & 1 & $.961^{* *}$ & $.963^{* *}$ \\
\hline & Sig. (2-tailed) & .000 & .000 & .000 & .000 & .000 & & .000 & .000 \\
\hline & $\mathrm{N}$ & 100 & 100 & 100 & 100 & 100 & 100 & 100 & 100 \\
\hline \multirow[t]{3}{*}{ NHR } & Pearson Correlation & $.910^{* *}$ & $.983^{* *}$ & $.976^{* *}$ & $.944^{* *}$ & $.991^{* *}$ & $961^{* *}$ & 1 & $.997^{* *}$ \\
\hline & Sig. (2-tailed) & .000 & .000 & .000 & .000 & .000 & .000 & & .000 \\
\hline & $\mathrm{N}$ & 100 & 100 & 100 & 100 & 100 & 100 & 100 & 100 \\
\hline \multirow[t]{3}{*}{ ID } & Pearson Correlation & $.909^{* *}$ & $.986^{* *}$ & $.979^{* *}$ & $.943^{* *}$ & $.988^{* *}$ & $.963^{* *}$ & $.997^{* *}$ & 1 \\
\hline & Sig. (2-tailed) & .000 & .000 & .000 & .000 & .000 & .000 & .000 & \\
\hline & $\mathrm{N}$ & 100 & 100 & 100 & 100 & 100 & 100 & 100 & 100 \\
\hline
\end{tabular}

**. Correlation is significant at the 0.01 level (2-

tailed).

Table 3: Correlations of Prospects.

The result of Pearson correlation coefficient ( $\mathrm{r}$ ) shows that tribal foods (DTF) $(\mathrm{r}=.892, \mathrm{p}<0.01)$, employment opportunity (EO) $(r=.909, p<0.01)$, Income level (IL) $(r=.954, p<0.01)$, Standard of living (SL) $(r=.922, p<0.01)$, economic development (ED) $(\mathrm{r}=.881, \mathrm{p}<0.01)$. number of hotel and restaurants $(\mathrm{NHR})(\mathrm{r}=.910, \mathrm{p}<0.01)$, infrastructure development(ID) $(\mathrm{r}=.909, \mathrm{p}<0.01)$, The analysis found that the factors i.e., tribal foods, bridges construction, employment opportunity, income level, the standard of living, economic development, number of hotel and restaurants, infrastructure development are significantly correlated with the prospects of tourism sectors of khagrachari.

\section{Findings}

10.1 Challenges of the tourism sector

Transportation

Transportation is the main challenge for the development of tourism sectors in khagrachari because it is a hilly area and the roads are very narrow in the maximum area that's why few years ago large, comfortable and luxurious buses were not available from khagrachari -dhaka or khagrachari - chittagong. Although at present few luxurious buses are available on these routes but tourists cannot travel from khagrachari Sadar to other tourists places comfortably. They have to hire jeep local people called chader gari but this is very much costly for the tourists that demotivated local tourists especially students and middle-class family to come here and visit the natural beauty of khagrachari. Through this research study, the researcher has found out that around $65 \%$ of 
respondents supposed that transportation facilities are not available in khagrachari.

\section{Accommodation}

Although in khagrachari sadar you will get available hotels for your accommodation but maximum tourists destination places you will not get enough accommodation facility. Even if you get a room for accommodation you will have to pay high rent for your night stay. There are no five-star hotels for the higher class people. Most of the hotels are mid-range. Rooms are very much congested in those hotels. Around $62 \%$ of respondents believe that accommodation facilities are not available in khagrachari

\section{Security}

The major concern for the tourist is security. Although Bangladesh ARMY is always careful about the safety of the people who come here for tour purposes but some occurrences like murder have happened in CHT that's why more than $50 \%$ of respondents are not satisfied with the tourist security. They are afraid of the local political conditions Tourists prefer those places where they can move with safety and feel secured.

\section{Roads and highways}

Roads and highways are very narrow in khagrachari Sadar to other destination areas. for example khagrachari to rangamati most of the part the road is so narrow the two minibusses cannot easily cross each other. Besides khagrachari to Sajek road condition is so much narrow that tourists cannot go to sajek by bus. They have to hire a jeep or CNG for traveling which is much costly than traveling by bus. $72 \%$ of the total respondents agree that roads and highways are very risky in khagrachari.

\section{Electricity}

The electricity problem is another crucial problem in khagrachari. Before 2018 there were at least 12 hours of load shedding every day. As it is hilly areas if the weather has slightly become bad or lightning flashes then the electricity goes for 8-12 hours sometimes local people do not get electricity service for 2-3 days. Educations, healthcare, business, and trading are being disrupted everywhere. Although in Sadar Upazila the electricity problem reduces recently but in most of the tourist places of khagrachari electricity is the main problem. From the survey, it can be said that although $40 \%$ of respondents are satisfied with the electricity services in khagrachari but $56 \%$ of respondents are irritated by the electricity services.

\section{Internet facility}

Internet service is the basic requirement for the tourists because they are always busy with capturing photos, shooting videos and want to share their experience in social media by uploading their up to date photos and videos for using laptops and smartphone they need internet facility but which is not available everywhere in CHT. $82 \%$ of respondents assume that $4 \mathrm{G}$ internet facility is a must in khagrachari for the development of tourism.

\section{Insufficient information on the website}

Tourist always seeks different kinds of information such as several visiting places, distance from one place to another, hotel and accommodation facilities, rent of the cars or other vehicles, and cost of other related information. When they do not find sufficient information on the internet then they become demotivated. 59\% of respondents supposed that information on websites regarding tourist spots of khagrachari is very insufficient.

\subsection{Prospects of tourism sectors}

Tribal foods:

Tourists who will come to khagrachari can taste various types of local foods like bamboo chicken which specialty is that food is stuffed and cooked inside bamboo, pajon which is a brilliant mix of numerous vegetables and shutki, Mangso Morich Godiye which is essentially similar to bhorta, chicken laksu (also called horbo) which means cooking 'pahari deshi' (native) chicken which has its unique taste. Besides these, there are some other local food available in khagrachari that are bachchuri, spicy crab bhuna,Binni chaal er payesh, taaba, maalah etc. $78 \%$ of total respondents assume that different types of tribal foods are found in khagrachari.

\section{Employment opportunity}

The tourism sector creates huge employment opportunities in any particular area. When the tourism sector develops in khagrachari number of hotels and restaurants will be increased which will require more people to deliver services to the target customers. More buses, auto, CNG, jeep will come to the road for the tourist that will create employment opportunities too. The survey result interprets that about $75 \%$ of tourists and local people believe that if tourism in khagrachari is more developed then more employment opportunities will be created.

Income level

If the tourism sector develops then more people will get a job related to tourism then their income level will increase. for example, when tourism will develop more, more bus services will be needed where more employees have to recruit, more hotels will be established where more people will be recruited as receptionists, bell person, room service, cleaners, chefs, bartenders, accountants, etc. when local people get the job then their income level will increase. Besides sales volume of grocery shops will increase because of the increasing food demand of tourists. So here grocery shops owner's income levels will increase. From the survey, the researcher has found 
that approximately $70 \%$ respondents' income level is somehow related to tourism whose income will increase by the development of tourism.

\section{Standard of living}

If the challenges can be overcome and tourism sector develop in khagrachari then more tourists will come to that area for the visiting purpose that creates employment opportunity that ultimately increases the standard of living because when people have an opportunity to earn money and increase the income level of that people then they can purchase more food to eat, they can spend more money for their family member education, health, clothes, and foods, etc. so it can be said that as many tourists will come to that area as much as the standard of living will be changed here. Through this research study, the researcher has bought out about $73 \%$ of respondents are confident that tourism sectors will change the standard of living although $20 \%$ of respondents do not agree with that.

\section{Growth of hotels and restaurants}

Last five years the number of hotels and restaurants increasing in a large number. Before 2015 there were only 56 hotels and around 10 restaurants exist in khagrachari Sadar where now there are more than 20 hotels are ready for providing the accommodation service and more than 50 restaurants are ready to serve food services to both local people and the tourists. There were no quality restaurants in Alutila before 5 years ago but now there are more than 5 quality restaurants in alutila. From the survey, it has found that $75 \%$ of respondents agree that number of hotels and restaurants will increase if tourism in khagrachari develops more.

\section{Infrastructural development}

Once upon a time, the infrastructure was very much dangerous in khagrachari. At that time maximum roads were very narrow and most of the bridges were made of steel. But with time the government has focused on the infrastructural development of the hill districts to make the life of the people risk-free and to attract more people to that area. Now roads have become wider than before and bridges are made of concrete and bricks in khagrachari. Three hill district councils and hill tracts development board are always trying to develop the infrastructure of these hill districts. $75 \%$ of respondents agree that infrastructural development will happen if the tourism sector develops.

\section{Economic Development}

The tourism sector is a crucial factor for the economic development of khagrachari. If challenges can be overcome by the government then the economy of this area will greatly change. If the Bangladesh government with the help of the local government, administration, police, and Bangladesh army can overcome the challenges low then millions of tourists will come to visit the natural beauty of khagrachari that will have a positive impact on infrastructure, transport, service sectors, and income level of that area. Finally, through the development of all the factors, it will heavily impact the economy of the khagrachari. Here the researcher has found that $80 \%$ of respondents out of total respondents believe that if the tourism sector develops then the economy will develop more.

\section{Recommendations}

$>$ Transportation facilities must be improved for the development of the tourism sector. Comfortable transportation must be available so that tourists can move to every tourist spot easily and at a low cost.

$>$ The local government must take necessary steps regarding establishing more hotels and motels for making accommodation facilities available in every tourist spot.

$>$ Accommodation facilities must be increased in remote spots of khagrachari so that tourists can stay in those places at night. In this case, proper security must be arranged by the local authority.

$>$ As tourists don't feel $100 \%$ secured in khagrachari so government must take initiatives for ensuring more security for the tourists and peace for the local community.

$>$ As roads and highways are very narrow so roads and highways must be wider as much as possible so that tourists can feel safe while traveling in khagrachari or driving in khagrachari

$>$ The electricity problem must be overcome as early as possible. If the electricity problem is solved then hotels and motels' utility costs will reduce and accommodation costs also reduce that ultimately satisfy tourists.

$>$ The local government has to come forward to make available network services in every tourist spot in khagrachari.

$>$ As there is a huge lacking's of tourist guides so local authorities must motivate local people to act as a tourist guides. Because in this way they can earn money and tourists can get complete guidelines regarding tourist places, accommodation, transportation, and food variation.

$>$ Tourists seek information on the internet regarding their destinations so information must be available about tourist spots, distance, transport, accommodation, foods, etc. 


\section{Conclusions}

Tourism is the fastest-growing sector in Bangladesh. To enjoy the prospects of the tourism sector in khagrachari it is important to overcome the challenges of the tourism sector. The transportation problem must be solved by developing roads and highways and introducing comfortable tourist buses for traveling to tourist spots. Electricity services must be available, more armed forces must employ to ensure more security for both local people and tourists. Information regarding all the tourists' spots must be available on the internet so that people can get a clear idea about their destination, its cost, distance, accommodation, and other facilities. If these problems can be overcome then the tourism sector will develop more and the economic situation and overall infrastructure of khagrachari will rapidly change because no other sector can change this hill district as much as the tourism sector can.

\section{References}

1. Alam, J. (2018), Problems and Prospects of Tourism Industry in Bangladesh: A Case of Cox's bazar Tourist Spots. International Journal of Science and Business, 2(4), 568-579. doi: https://doi.org/10.5281/zenodo. 1433720

2. Chew, Joseph. 1987. "Transport and Tourism in the Year 2000." Tourism Management 8 (2): 83-85. Doi: 10.1016/0261-5177(87)90003-3.

3. Getz, D., Robinson, R., Andersson, T., \& Vujicic, S. (2014). Foodies \& food tourism. Oxford: Goodfellow Publishers, Ltd.

4. Hall, C. M., Sharples, L., Michell, R., Macionis, N., \& Cambourne, B. (2003). Food tourism around the world. Oxford: Butterworth-Heinemann.

5. Hjalager, A. M., \& Richards, G. (2002). Tourism and Gastronomy. London: Routledge

6. Khan, MT. (2015). Securitisation of tourism in CHT, New Age, 12 June, viewed 1 September 2016, $<$ http://newagebd.net/128368/securitisation-of-tourism-in-cht/ >

7. Khondker, B. H., \& Ahsan, T. (2015). Background Paper on Tourism Sector.

8. Lamb, Barbara, and Sally Davidson. 1996. "Tourism and Transportation in Ontario, Canada: A Vital Link." In Practicing Responsible Tourism: International Case Studies in Tourism Planning, Policy and Development. John Wiley and Sons.

9. Liu, J. (2007). Econometric Analysis of Tourism Consumption of Urban Residents in China. Business Culture.

10. Nabi, N., \& Zaman, S. (2014). The Sources and Availability of Information for Tourists: A Study on Tourism Sector of Bangladesh. World Journal of Social Sciences Vol. 4. No. 1. , $154-166$.

11. Powering Tourism: Electrification And Efficiency Options For Rural Tourism Facilities (2005)(USAID)

12. Rachão, S., Z. Breda, C. Fernandes and V. Joukes (2019) Food tourism and regional development: A systematic literature review. European Journal of Tourism Research 21, pp. 33-49

13. Ramadan Mazrekaj, Impact of Road Infrastructure on Tourism Development in Kosovo, International Journal of Management, 11 (4), 2020, pp. 466-474.

14. Rokanuzzaman, Mohammad. (2019). Tourism and its Potentiality of Creating Employment Opportunities in Bangladesh.

15. Sharpley, Richard. (2000). the influence of the accommodation sector on tourism development: lessons from Cyprus. International Journal of Hospitality Management. 19. 275-293. 10.1016/S0278-4319(00)00021-9.

16. Tanzina Chowdhury, Syeda Tamanna Fahim, Evana Nusrat Dooty(2013) Promoting Public Private Partnership for Development ofTourism Sector of Bangladesh: An Exploratory Study. European Journal of Business and Management ISSN 2222-1905 (Paper) ISSN 2222-2839 (Online) Vol.5, No.32, 2013

17. Uddin, N. (2010). Politics of cultural difference: Identity and marginality in the Chittagong Hill Tracts of Bangladesh, South Asian Survey, vol. 17, no. 2, pp. 283-294.

18. https://www.bbc.com/bengali/news-53458759

19. https://www.dw.com/bn/

20. https://www.thedailystar.net/lifestyle/news/ethnic-treats-chittagong-hill-tracts-dhaka-2045505

21. Life is not ours: the Chittagong Hill Tracts Commission $\backslash$

22. https://www.angelfire.com/ab/jumma/resist/military.html

23. http://www.bangladeshtourism.gov.bd : Bangladesh Parjatan Corporation (BPC).

24. http://www.parjatan.gov.bd/tourism :Website of Ministry of Civil Aviation

25. http://www.tourismboard.gov.bd: Tourism Policy-Bangladesh Tourism Board (National Tourism Organization)

26. https://thefinancialexpress.com.bd/economy/bangladesh/tourist-arrivals-rise-in-five-years-1569469201

27. http://m.theindependentbd.com//post/148567

28. https://wttc.org/enn-gb/Research/Insights 